\title{
Teaching NeuroImages: Hypertrophic polyneuropathy
}

Luke Dixon, MBBS, FRCR, and Sachit Shah, MBBS, FRCR

Neurolog $y^{\circledR}$ 2020;95:e779-e780. doi:10.1212/WNL.0000000000010025

Figure Fat-suppressed T2-weighted MRI of the lumbar plexus

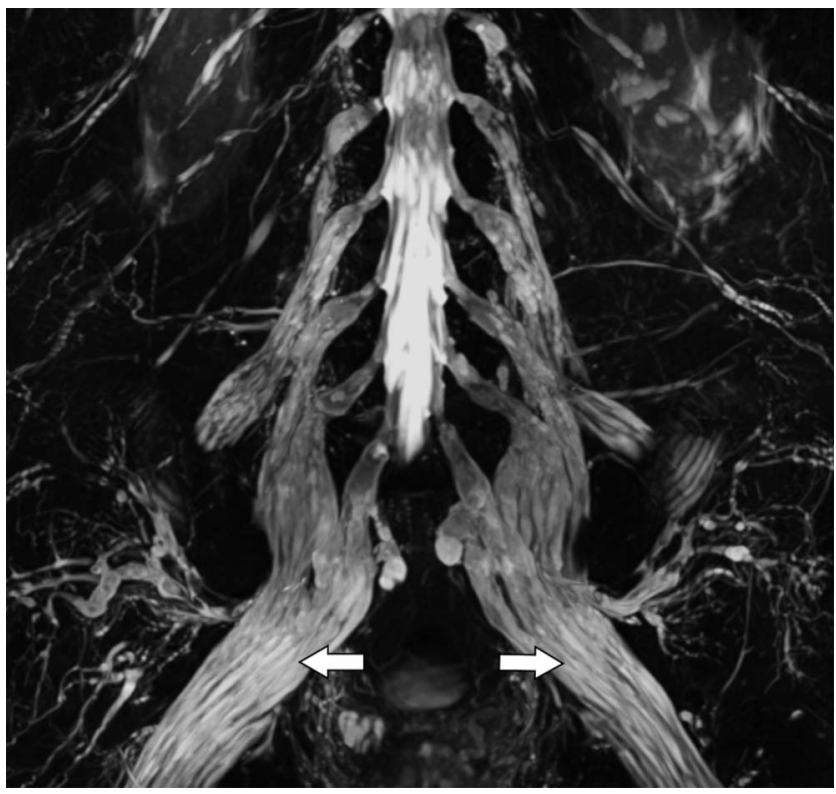

MRI demonstrates striking symmetrical thickening and abnormal signal of the lumbar plexus and imaged peripheral nerves (arrows: thickened sciatic nerves).

A 75-year-old man previously diagnosed with multiple sclerosis presented with a 20 -year history of therapy-resistant progressive upper and lower limb weakness and sensory deficits. Examination found hand interossei muscle wasting, thickened radius and ulna nerves, and reduced distal lower limb strength. Neurophysiology revealed a sensorimotor polyneuropathy with demyelinating features. MRI showed hypertrophic nerves and nerve roots in the lumbosacral plexus (figure). Charcot-Marie Tooth disease (CMT) and chronic inflammatory demyelinating polyneuropathy (CIDP) are the leading causes of hypertrophic polyneuropathy. Other causes include leprosy, neurofibromatosis and amyloid deposition. In this case, genetic screening was negative for CMT, suggesting probable CIDP.

\section{Study funding}

No targeted funding reported.

\section{Disclosure}

The authors report no disclosures relevant to the manuscript. Go to Neurology.org/N for full disclosures.

\section{Correspondence}

Dr. Dixon

Luke.dixon1@nhs.net

\section{MORE ONLINE}

$\rightarrow$ Teaching slides

links.lww.com/WNL/

B136 
Appendix Authors

\begin{tabular}{lll}
\hline Name & Location & Contribution \\
\hline $\begin{array}{l}\text { Luke Dixon, } \\
\text { MBBS, FRCR }\end{array}$ & $\begin{array}{l}\text { Queen Square, } \\
\text { London, UK }\end{array}$ & $\begin{array}{l}\text { Interpreted the data, drafted the } \\
\text { manuscript for intellectual content }\end{array}$ \\
\hline $\begin{array}{l}\text { Sachit Shah, } \\
\text { MBBS, FRCR }\end{array}$ & $\begin{array}{l}\text { Queen Square, } \\
\text { London, UK }\end{array}$ & $\begin{array}{l}\text { Interpreted the data, revised the } \\
\text { manuscript for intellectual content }\end{array}$ \\
\hline
\end{tabular}




\section{Neurology}

\section{Teaching NeuroImages: Hypertrophic polyneuropathy \\ Luke Dixon and Sachit Shah \\ Neurology 2020;95;e779-e780 Published Online before print July 8, 2020 \\ DOI 10.1212/WNL.0000000000010025}

This information is current as of July 8, 2020

\section{Updated Information \&} Services

Subspecialty Collections

Permissions \& Licensing

Reprints including high resolution figures, can be found at: http://n.neurology.org/content/95/6/e779.full

This article, along with others on similar topics, appears in the following collection(s):

\section{Clinical neurology examination}

http://n.neurology.org/cgi/collection/clinical_neurology_examination EMG

http://n.neurology.org/cgi/collection/emg

Peripheral neuropathy

http://n.neurology.org/cgi/collection/peripheral_neuropathy

Information about reproducing this article in parts (figures,tables) or in its entirety can be found online at:

http://www.neurology.org/about/about_the_journal\#permissions

Information about ordering reprints can be found online:

http://n.neurology.org/subscribers/advertise

Neurology ${ }^{\circledR}$ is the official journal of the American Academy of Neurology. Published continuously since 1951, it is now a weekly with 48 issues per year. Copyright @ 2020 American Academy of Neurology. All rights reserved. Print ISSN: 0028-3878. Online ISSN: 1526-632X.

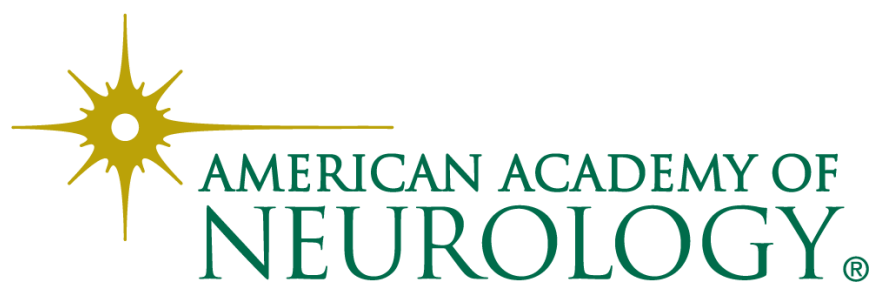

